\title{
The Trouble with Zombies: Bare Life, Muselmänner and Displaced People
}

\author{
Jon Stratton
}

This article is about the relationship between zombies and displaced people, most obviously those categorised as refugees, asylum seekers and illegal immigrants. It is founded on a realisation that the underlying characteristics of zombies are similar to those attributed to displaced people - people, predominantly from non-Western states, striving for entry into Western states. Underlying both the zombie and the displaced person is the idea of 'bare life' as elaborated by Giorgio Agamben. I will be arguing that what audiences find most frightening in the zombie idea is not the resurrection from death but that state of living death which is the fate of the zombie. Indeed, in some films that are identified as a part of the zombie genre, such as the recent 28 Days Later (2003), the person doesn't even die before turning into what is now being described as a zombie. In this case, if the key to the identification of a zombie is the interstitial state of being between life and death then, I will argue, the zombie takes on the characteristic of bare life. Bare life is difficult to define because it has two aspects. The first is, for want of a better word, social. Setting up his discussion of the relationship between bare life and aesthetics, Anthony Downey writes that:

Lives lived on the margins of social, political, cultural, economic and geographical borders are lives half lived. Denied access to legal, economic and political redress, these lives exist in a limbo-like state that is largely preoccupied with acquiring and sustaining the essentials of life. The refugee, the political prisoner, the disappeared, the victim of torture, the dispossessed - all have been excluded, to different degrees,

Somatechnics 1.1 (2011): 188-208

DOI: 10.3366/soma.2011.0013

(C) Edinburgh University Press

www.eupjournals.com/soma 


\section{The Trouble with Zombies}

from the fraternity of the social sphere, appeal to the safety net of the nation-state and recourse to international law. They have been outlawed, so to speak, placed beyond recourse to law and yet still in a precarious relationship to law itself. (2009: 109)

Members of all these groups, including displaced people, can be thought of as experiencing bare life in its modern form.

The second aspect that bare life describes is the existential state of a person placed in this circumstance. Following Agamben, I will argue that the typifying existential state is that to which many Jews were reduced in the concentration and death camps of Nazi Germany; a person in this condition was called in many camps a Muselmann. This state, often described as a living death, closely resembles that of the zombie. The difference being that zombies, living after death, are portrayed as fundamentally threatening to the living while the Muselmänner lived only until their transformation into the dead was complete. The point here is twofold. First, that, excluded from the rights and privileges of the modern state, those displaced people are positioned legally as bare life. Second, in this legal limbo, these people can be treated in a way that enables them to become associated with a condition mythically exemplified in the zombie. The consequence is that not only can the zombie texts of films and other media be read as reproducing this connection, drawing on present-day anxieties to increase the terror produced by these texts, but displaced people are characterised using the same terminology that describes the threat that zombies generate in zombie apocalypse texts.

This article begins from the recognition that during the 2000s there has been a tremendous increase in the number of films released featuring zombies. At the same time, zombies have started appearing in other media. A video game series called Resident Evil, which includes biologically mutated flesh-eating undead, founded a genre now called 'survival horror'. Released originally for Sony PlayStation in 1996, by September $30^{\text {th }}, 2004$, the various forms of the game had sold over 25 million units ('Capcom's million-selling series' 2004). In 2002 it spawned a film also called Resident Evil. The film became the fourteenth highest grossing ' $R$ ' rated film in the United States that year and the fiftieth highest grossing film globally ('Resident Evil' n.d.). There are now two sequels. In 2009, Quirk Books released Pride and Prejudice and Zombies, a mash-up in which author Seth Grahame-Smith introduced zombies into Jane Austen's 1813 romance novel. The book became an instant success. In April it had reached the third spot on the 
New York Times bestseller list and by the end of the year it had sold over 700,000 copies (Merritt 2009). Such was the success of the revisioned novel that Quirk Books were inspired to commission a prequel, Steve Hockensmith's Pride and Prejudice and Zombies: Dawn of the Dreadfuls.

During the same period, since the 1990s, there has been an increasing anxiety in Western countries over the numbers of displaced people attempting to gain entry across their borders. The reasons for this are many but not my main concern here. Certainly there has been an overall increase in refugee numbers. One set of figures released by the United Nations High Commissioner for Refugees (UNHCR) tell us that where in 1960 there were $1,656,669$ people classified as refugees, in 2006 this had climbed to $9,877,703 .{ }^{1}$ However, most of these refugees are situated in countries outside the developed West. Similarly, between 1980 and 2000 there has been a significant increase in asylum seeker applications in Europe, from around 150,000 to around 450,000 with a spike up to 700,000 in the early 1990 s and in Australia and New Zealand from virtually nothing in the mid-1980s to around 5000 a year. In North America the figure increased significantly in the mid-1990s to nearly 200,000 and then declined to around 50,000 by $2000 .^{2}$ Anxieties over border protection in all countries but, perhaps, especially in the West, were heightened in the wake of the 2001 attacks on the World Trade Center in New York The link between these anxieties and concerns over displaced people attempting to gain entry to Western countries was made in, for example, Children of Men, released in 2006 and set in 2027. Directed by Alfonso Cuarón, who also co-wrote the screenplay, the backdrop to the film's ostensible concern with global infertility is a Great Britain in which the increase in unsanctioned immigration is such that asylum seekers are placed in cages on London's streets and Bexhill-on-Sea, on the south coast, has been turned into a massive detention camp (see Stratton 2009).

In many of the recent zombie texts, the zombie threat can be read in terms of the fears of many members of Western countries about being overwhelmed by displaced people. What might be the justification for this connection between zombies and displaced people? The recent renaissance in zombie films lifts off from the revision of zombies in Western popular culture that is traced to George A. Romero's now classic 1968 film, Night of the Living Dead. This film began what is now colloquially called the zombie apocalypse trope in which entire communities, whole countries, and even the world, are subject to destruction by increasing numbers of zombies that appear from nowhere, often originating as a consequence of radiation from 
outer space - if any rationale for their existence is proffered. In these films the zombie presence is qualitatively different from the earlier zombie trope, derived from claims about the existence of zombies in Haiti, in which witches or evil scientists turned individuals into zombies as a means of controlling them. Nevertheless, the foundational idea of the zombie as a dead person resurrected to a state that remains nearer death than life is a constant.

\section{The Popularity of Zombies}

Through the first decade of the twenty-first century there has been a great increase in the cultural presence of zombies. In January 2006, Steven Wells, in an article in The Guardian, wrote that, 'there were zombies everywhere in 2005' (quoted in Bishop 2009: 19). That same year, in March, Warren St. John in the New York Times commented that: 'In films, books and video games, the undead are once again on the march, elbowing past werewolves, vampires, swamp things and mummies to become the post-millennial ghoul of the moment' (quoted in Bishop 2009: 19). What St. John's remark signals is something quite important, that it is not just that there has been an increase in visibility of zombies as a consequence of their appearance in an increased number of texts but that this increase outstrips other conventional horror characters such as werewolves and vampires. Agamben has discussed the werewolf and I shall return to this creature later.

As Simon Pegg, the writer of, and actor in, Shaun of the Dead, a British zombie film released in 2004, remarks: 'As monsters from the id, zombies win out over vampires and werewolves when it comes to the title of Most Potent Metaphorical Monster' (Pegg 2008). Zombies have become the most important mythic monster at the present time. Peter Dendle, in an astute discussion of the zombie phenomenon writes about 'the resurgence of zombie movie popularity in the early 2000s' (2007: 54). For him, this 'has been linked with the events of September 11, 2001' (2007: 54). Making a different claim to Pegg's, but one that is still generalising, Dendle goes on to argue that,

apocalypticism has always been ingrained into the archetypal psyche of any society defining itself - as all human endeavours must - in the context of history and time. The possibility of wide-scale destruction and devastation which 9-11 brought once again into the communal consciousness found a ready narrative expression in the zombie apocalypses which over thirty years had honed images of desperation subsistence and amoral survivalism to a fine edge. (2007: 54) 
Following Dendle, Kyle Bishop makes a similar point: 'Although the conventions of the zombie genre remain largely unchanged, the movies' relevance has become all the more clear - a post-9/11 audience cannot help but perceive the characteristics of zombie cinema through the filter of terrorist threats and apocalyptic reality' (2009: 24). As we shall see, there is certainly a link between zombies and a terrorist threat that is claimed to be of Islamic origin. And, it can be argued, as both Dendle and Bishop have done, that 9/11 had a considerable impact on the American national imaginary and that this is expressed in the way that Americans make, and read, zombie films.

However, films made outside the United States, and even a recent American zombie film such as Romero's Land of the Dead, released in 2005 , evidence a quite different anxiety. To understand this, we need to begin with a discussion of what constitutes a zombie. Dendle argues that:

The essence of the 'zombie' at the most abstract level is supplanted, stolen, or effaced consciousness; it casts allegorically the appropriation of one person's will by another. It is no coincidence that the creature flourished in the twentieth century, a century whose broad intellectual trends were preoccupied with alienation. (2007: 47-8)

Dendle is here extrapolating from a history that refers back to the zombie as a characteristic of Haitian voodoo. In doing so he elides the recognition that the zombies of the zombie apocalypse films after Romero's Night of the Living Dead are often not created by someone. They do not have will but they are not in somebody's control. Indeed, this is one of things that make them so frightening; their existence is entirely alien. We shall see that this is one way that the zombie as terrorist threat functions. That is, while in the American, and indeed Western, imaginary, terrorists are thought to be controlled by some evil master, usually personified as Osama bin Laden, they are also thought to be a mindless threat coming from outside the West, from outside any Western country.

Dendle traces the American popular cultural interest in zombies to the American occupation of Haiti between 1915 and 1934. He writes that:

Ghosts and revenants are known world-wide, but few are so consistently associated with economy and labour as the shambling corpse of Haitian vodun, brought back from the dead to toil in the fields and factories by miserly land-owners or by spiteful houngan or bokor priests... The zombie, a soulless hulk mindlessly working at the bidding of another, 


\section{The Trouble with Zombies}

thus records a residual communal memory of slavery: of living a life without dignity and meaning, of going through the motions. (Dendle 2007: 47)

Dendle links the rise of American interest in zombies to the Great Depression and the crisis of labour. It is an important point. In postNight of the Living Dead zombie apocalypse films, the link between the zombie and slavery, and by extension the worker in a capitalist economy, has been repressed. In the films where the zombies can be read as displaced people, this connection is reappearing.

Joan Dayan, an anthropologist, has recently provided this description of the zombie: 'Born out of the experience of slavery and the sea passage from Africa to the New World, the zombi ${ }^{3}$ tells the story of colonization: the reduction of human into thing for the ends of capital. For the Haitian no fate is to be more feared' (1997: 33). Dayan goes on to explain that, in the present day:

In a contemporary Caribbean of development American style, the zombi phenomenon obviously goes beyond the machinations of the local boco. As Depestre puts it, 'This fantastic process of reification and assimilation means the total loss of my identity, the psychological annihilation of my being, my zombification.' And Laënnec Hurbon explains how the zombi stories produce and capitalize on an internalization of slavery and passivity, making the victims of an oppressive social system the cause: 'The phantasm of the zombi ... does nothing but attest to the fulfilment of a system that moves the victim to internalize his condition.' (1997: 33)

Dayan's purpose is to explain how, in the present Haitian context, the zombie functions as an explanation for the destruction of Haitian culture by American colonialism disguised as development. The mindless zombie, labouring for another, becomes a way of understanding the impact of American capital on Haiti and the Caribbean more generally.

Jean Comaroff and John Comaroff make a similar point about the rise in zombie stories in South Africa. They write that:

There can be no denying the latter-day preoccupation with zombies in rural South Africa. Their existence, far from being the subject of elusive tales from the backwoods, of fantastic fables from the veld, is widely taken for granted. As a simple matter of fact. In recent times, respectable local newspapers have carried banner headlines like 'Zombie Back from the Dead' illustrating their stories with conventional, high-realist photographs. (Comaroff and Comaroff 2002: 786-7) 
The Comaroffs argue that the zombie narrative is a useful way for people who do not understand the complexities of international, neoliberal capitalism to account for how some people seemingly get rich very quickly without doing any visible work: they create zombies who work for them and do not have to be paid. Looking over the history of zombies in Africa, the Comaroffs write that: 'Zombies themselves seem to be born, at least in the first instance, of colonial encounters, of the precipitous engagement of local worlds with imperial economies that seek to exert control over the essential means of producing value, means like land and labor, space and time' (2002: 795). In other words, at a conceptual level, zombies are a local response of the colonised to the impact of colonial capitalism, a way of understanding how those capitalist practices produce wealth for some and immiseration for others.

\section{Zombies, Bare Life and Muslims}

Comaroff and Comaroff write that:

The fear of being reduced to ghost labor, of being abducted to feed the fortunes of a depraved stranger, occurs alongside another kind of specter: a growing mass, a shadowy alien-nation, of immigrant black workers from elsewhere on the continent. Like zombies, they are nightmare citizens, their rootlessness threatening to siphon off the remaining, rapidly diminishing prosperity of the indigenous population. (2002: 789)

The Comaroffs are describing how poor, black South Africans experience the displaced people arriving in South Africa through its porous land border. One of the established themes of zombie apocalypse films is the siege - the scene where the humans seek sanctuary somewhere and find themselves surrounded and besieged by increasing numbers of zombies striving to get in.

At this point I turn to Romero's first film, the film that transformed the zombie genre: Night of the Living Dead. The film offers little more than the siege theme. Seven people find themselves trapped in a house and attempt to protect themselves from zombie attack as gradually each, except one, is killed by the zombies, or in the case of the young daughter, becomes a zombie, eating her father and killing her mother. ${ }^{4}$ What, ultimately, was so shocking about this film was its nihilism. The man who survives the zombie attack is himself killed in the mistaken belief that he is a zombie. The first thing to know about this low-budget, black and white film is that Romero never 
envisaged it as a zombie film. He thought of the creatures as ghouls. As he has said: 'I never called them zombies, I called them "flesheaters" or "ghouls" - back then, zombies were those boys in the Caribbean who were doing wetwork for Lugosi - I never thought of them as zombies' (quoted in Rocchi 2008). Ghouls are demons that entered Western popular culture from the Arab world in the nineteenth century. They are supposed to haunt graveyards and feed on the flesh of corpses. Indeed, Romero's original title for the film was Night of the Flesh Eaters. The title was changed by someone at the Walter Reade Organization, the film's distributors, because of objections that it was too similar to a film called The Flesh Eaters, released in 1964. I will write about the importance of the new title later. Here, it is necessary to realise how the change of name, which was not Romero's doing, contributed to the change in the type of creature that audiences thought was being depicted. When the film was released, these were still understood to be ghouls. Roger Ebert, for example, in a review published in Readers' Digest in January 1967, in which he discussed his shock at the horrifying nature of the film, wrote about the creatures as ghouls.

It is unclear when the creatures became zombies but this probably took place around the end of the 1970s. When Romero's sequel, Dawn of the Dead was released in the United States in 1978, he was still thinking of the creatures as ghouls. When the film was released in Italy it was called Zombi, and Lucio Fulci's notorious Zombi 2 was given that title as if it was somehow related to the Romero film. In the United States, when it was released in 1980, Fulci's film was titled Zombie. At the same time, Variety, in a negative review of Dawn of the Dead, published in January 1979, that rivalled the paper's earlier review of Night of the Living Dead, described the creatures as 'carnivorous corpses' ('Dawn of the Dead' 1979). In many European countries, such as Italy, Greece, West Germany and France, the film carried a title associating it with zombies. What seems to have justified the changed perception of Romero's creatures is that they were resurrected corpses.

The shift from ghouls to zombies brought a different set of connotations into play. Romero's father was a Cuban migrant. His mother was from Lithuania. Romero tells this story about his father who always denied he was Cuban and claimed his family was from Spain: 'I grew up in New York with a Spanish dad right in the days of West Side Story, where you know the Puerto Rican gangs and shit? My dad telling me Puerto Ricans are shit. I have a Latino dad who's telling me that Puerto Ricans are shit (laughs). I mean this is a very confusing situation' (Romero in interview with Lee Kerr, quoted in Casares 2009). Commenting on this autobiography, Cindy Casares 
writes: 'Perhaps this confusion is what led Romero to express his angst through monsters' (2009). Seemingly glossing Romero, she goes on: 'he got the idea for a low-budget horror film with an apocalyptic theme about the invasion of a new kind of monster - a monster that was tearing the world as we knew it apart because the audience didn't know who was one and who wasn't' (2009). Could these monsters be migrants transforming America's racial structure? Eric Hamako notes that: 'George Romero has raised - and critiqued - the idea of Latino immigration and zombies-as-Latinos, in at least two of his films. ${ }^{5}$ Of course, the audience could tell who was a monster and who was not. However, the white men hunting down the zombies in Night of the Living Dead seem unable to make the differentiation. The man who is mistaken for a zombie and shot dead is African American. Reading this in terms of American race relations, a possible interpretation, can distract from reading the zombies as non-white migrants. These invading monsters were even more threatening than a black American who had taken charge and successfully defended the besieged house; these were mindless, living dead.

To understand the foundation of the new configuration of the zombie trope we need to think about Giorgio Agamben's idea of bare life. Bare life is key to understanding the functioning of the modern state. Indeed, the presence of bare life within the state is foundational to its form. Agamben begins by distinguishing two complementary ways of thinking about life as they are used by Aristotle. These are zoe and bios. Zoe is a term that unites species-being and embodiment. Bios can be translated as 'form of life'. It can be used to think about how zoē is lived. Agamben writes that: 'In the classical world ... simple natural life is excluded from the polis in the strict sense and remains confined as merely reproductive life - to the sphere of the oikos, "home" (1998: 2). 'Simple natural life' is a translation of zoē. This is not bare life. Bare life is the constituting feature of political life. As Agamben describes it: 'No simple natural life, but life exposed to death (bare life or sacred life) is the originary political element' (1998: 88, emphasis in original). Sacred life is a reference to a particular Roman legal idea. Agamben uses it as a way of defining not only bare life but also sovereignty: 'The sovereign sphere is the sphere in which it is permitted to kill without committing homicide and without celebrating a sacrifice, and sacred life - that is, life that may be killed but not sacrificed - is the life that has been captured in this sphere' (1998: 83, emphasis in original). Bare life is a description of life in a political context.

If $z o \bar{e}$ is simple natural life, bare life is what gives meaning to sovereignty. However, this life is revealed in its exclusion from 


\section{The Trouble with Zombies}

pre-modern political life: 'The sovereign and homo sacer are joined in the figure of an action that, excepting itself from both human and divine law, from both nomos and physis, nevertheless delimits what is, in a certain sense, the first properly political space of the West distinct from both the religious and the profane sphere, from both the natural order and the regular judicial order' (Agamben 1998: 84). Homo sacer, and its equivalents in other pre-modern political orders, is the person who does not have the protection of the sovereign. It is not the state that has the right to kill this person reduced to bare life but anybody. This person exists on the borderline of the polis, both included and excluded - their inclusion making their exclusion possible. Death marks the limit of sovereignty.

Agamben goes on to make another point which will be important later in my argument: 'Contrary to our modern habit of representing the political realm in terms of citizens' rights, free will, and social contracts, from the point of view of sovereignty only bare life is authentically political (1998: 106, emphasis in original). Here, Agamben is extending the idea of bare life into the practice of the modern state. But more of this shortly.

Agamben illustrates his point that bare life exists on the margin of the pre-modern state with a discussion of the werewolf. He explains that: 'Germanic and Anglo-Saxon sources underline the bandit's liminal status by defining him as a wolf-man' (Agamben 1998: 105). The bandit was the medieval equivalent of homo sacer. Agamben continues:

What had to remain in the collective unconscious as a monstrous hybrid of human and animal, divided between the forest and the city - the werewolf - is, therefore, in its origin the figure of the man who has been banned from the city. That such a man is defined as a wolf ... is decisive here. The life of the bandit, like that of the sacred man, is not a piece of animal nature without any relation to the city. It is, rather, a threshold of indistinction and of passage between animal and man, physis and nomos, exclusion and inclusion: the life of the bandit is the life of loup garou, the werewolf, who is precisely neither man nor beast, and who dwells paradoxically within both while belonging to neither. (1998: 105, emphasis in original)

Agamben is implicitly reworking Claude Lévi-Strauss' idea that myths ultimately mediate between culture and society. Here, the werewolf was a way that members of pre-modern political orders could understand the relationship between existence in a political order and the natural world, that is, the place of bare life. We should also note, and it is 
something to which we shall return, that being excluded from the polis diminishes a person's humanity. They exist between human and animal. The werewolf, like the bandit, is essentially predatory, threatening the existence of the polis while living off it. It both requires the polis but threatens its destruction. In the modern world the position of bare life changed fundamentally. In doing so, the power of the werewolf myth dissipated. What I want to suggest is that, equating with the werewolf in the pre-modern world, the zombie has become the emblematic figure for bare life in the modern world.

Agamben argues that, 'the entry of zoe into the sphere of the polis - the politicization of bare life as such - constitutes the decisive event of modernity and signals a radical transformation of the politicalphilosophical categories of classical thought' (1998: 4). As we have seen, $z o \bar{e}$ is not bare life but its presence within the arena of the political transforms it into bare life. Elsewhere, referring to Michel Foucault's work, Agamben provides a more extensive insight into this crucial political shift:

In its traditional form, which is that of territorial sovereignty, power defines itself essentially as the right over life and death; it concerns life only indirectly, as the abstention of the right to kill. This is why Foucault characterizes sovereignty through the formula to make die and to let live. When, starting with the seventeenth century and the birth of the science of police, care for the life and health of subjects began to occupy an increasing place in the mechanisms and calculations of states, sovereign power is progressively transformed into what Foucault calls 'biopower'. (1999: 82)

At this point, bare life, which previously existed on the margin of political orders, now begins its move to becoming the basis of political practice; to quote Agamben, "in modernity life is more and more clearly placed at the center of State politics (which now becomes in Foucault's term, biopolitics) ... in our age all citizens can be said, in a specific but extremely real sense, to appear virtually as homines sacri' (1998: 111). Agamben does not mean that anybody is allowed to kill the citizen of such a state. Rather, the lives of everybody within the state are governed by the power of the sovereign; everybody exists not as potentially bare life but as bare life with a reprieve.

The consequence is itself horrifying: 'It is almost as if, starting from a certain point, every decisive political event were double-sided: the spaces, the liberties and the rights won by individuals in their conflicts with central powers always simultaneously prepared a tacit but increasing inscription of individuals' lives within the state order, thus 
offering a new and more dreadful foundation for the very sovereign power from which they wanted to liberate themselves' (Agamben 1998: 121). Bare life has become increasingly cloaked with the panoply of citizenship and rights but this is simply a disguise for what is really at stake in modern politics, bare life itself.

We now need to make a brief detour. Gil Anidjar has written a history of the development of the discursive construction of Muslims in the modern West. His interest is in how the Muslim world has come to be understood in the political terms of despotism and total subjection. He explains that it was Montesquieu, following Jean Bodin, who first introduced the idea of despotism as a political form. Anidjar details this:

The invention of despotism ... involves the translation of a domestic term into a political one - the despotes was the head of the household, not a political figure. Yet this inventive gesture was structurally linked to another no less potent, if perhaps less visible invention: the 'apathy' and the 'faithful resignation' of the despot's subjects. What emerged at this momentous historical point in the writings of Montesquieu and others was also the invention of absolute subjection, its rapid and unceasing translation ... religion and politics as the conflictual union of incomparables. (2003: 125)

Anidjar quotes from Montesquieu's De l'esprit des lois, published late in his life in 1748: "The flood tide of Mahommedans brought despotism with it," and despotic government "is most agreeable" to the Mahommedan religion' (2003: 126). Glossing Montesquieu, Anidjar writes that: 'Such subjection, like blind fatalism, excludes reason and excludes one from reason' (2003: 127). Anidjar notes that Montesquieu describes despotism, and its associated absolute subjection, as an absurdity. We might think it not so much an absurdity as a fantastic description of the dark side of the modern politics that Agamben outlines. Despotism and mindless submission represent the possibility of modern politics once bare life has been made its foundation. Montesquieu, and later thinkers from Kant to Hegel and onwards, image this awful phantasm as the political life of the orientalised Other, Muslims.

Anidjar takes one more step. His interest is in how a certain type in the concentration and death camps of Nazi Germany came to be called Muselmänner, Jews who become identified as Muslims. The immediate question is why these victims of the camps were named Muslims. In an insightful and complex discussion that does not concern us here, Anidjar suggests that: 'As figures of absolute 
subjection, the Muslims can no doubt represent a degree zero of power, the sheer absence of a political displaced by a (negative) theology' (2003: 145). The Jews in the camps who had lost their ability to think, lost their will, appeared like the fantastic absurdity of Muslims under a despotic religio-political regime.

\section{Muselmänner and Zombies}

We now need to consider these Muslims, Muselmänner. The locus classicus for the Muselmann is Primo Levi's account in his first book called in its original Italian, Se questo è un uomo and published in England as If This Is a Man and in the United States as Survival in Auschwitz:

To sink is the easiest of matters; it is enough to carry out all the orders one receives, to eat only the ration, to observe the discipline of the work and the camp. Experience showed that only exceptionally could one survive more than three months in this way. All the mussulmans who finished in the gas chambers have the same story, or more exactly, have no story; they followed the slope down to the bottom, like streams that run down to the sea. On their entry into the camp, through basic incapacity, or by misfortune, or through some banal accident, they are overcome before they can adapt themselves; they are beaten by time, they do not begin to learn German, to disentangle the infernal knot of laws and prohibitions until their body is already in decay, and nothing can save them from selections or from death by exhaustion. Their life is short but their number is endless; they, the Muselmänner, the drowned, form the backbone of the camp, an anonymous mass, continually renewed and always identical, of non-men who march and labor in silence, the divine spark dead within them, already too empty to really suffer. One hesitates to call them living: one hesitates to call their death death, in the face of which they have no fear, as they are too tired to understand. (1996: 83)

We can add to this description from an account published by Agamben in Remnants of Auschwitz:

The other inmates avoided Muselmänner. There could be no common subject of conversation between them, since Muselmänner only fantasized and spoke about food ... 'I can still see them returning back from work in lines of five. The first line of five would march according to the rhythm of the orchestra, but the next line would already be incapable of keeping up with them. The five behind them would lean against each other; and in the last lines the four strongest would carry the weakest one by his arms and legs, since he was dying'. (Bronislaw Goscinki quoted in Agamben 1999: 169-70) 
These descriptions of Muselmänner make them appear remarkably similar to the creatures invented by Romero, the ones that by the end of the 1970s were beginning to be called zombies. I do not want to suggest that Romero had read Levi. Rather, Romero was tapping into an anxiety about those excluded from the protection of the modern state, those reduced to bare life.

Like Romero's creatures, Muselmänner have no will, they stagger along, they are interested in only one thing, food, and they do not speak. In a similar fashion, the zombie attribute is a groan. Here we can think about Elaine Scarry's comment on the experience of severe pain: 'Physical pain does not simply resist language but actively destroys it, bringing about an immediate reversion to a state anterior to language, to the sounds and cries a human being makes makes before language is learnt' (1985: 4). The zombie is a creature without language, which Western thought has considered a founding characteristic of human society. The zombie groan can be read as the expression of the pain of bare life, of the living dead.

It is instructive that, when the title of Romero's film was changed, the new title included the words 'living dead'. Since then, this has become the characteristic description of zombies. It is also a term often used to describe the Muselmänner. Aldo Carpi may have been the first person to actually have applied the term 'living dead' to the Muselmänner in his Diario di Gusen, the diary he kept of his time in that concentration camp, first published in 1971. In the translation given in Remnants of Auschwitz: 'I remember that while we were going down the stairs leading to the baths, they had us accompanied by a group of Muselmänner, as we later called them - mummy-men, the living dead' (Agamben 1999: 41). In the title of Romero's film, 'living dead' is an inspired shorthand for Levi's: 'One hesitates to call them living: one hesitates to call their death death'. The translation, Survival in Auschwitz, had been published in the United States in 1961. However, JoAnn Cannon tells us, 'it seems hardly to have been noticed when it first appeared' but Holocaust literature 'began to be read as a subgenre in the mid-sixties' (1992: 33). It is possible that someone in the Walter Reade Organization made the connection. But perhaps not. By the late 1960s there was a growing awareness of what was beginning to be termed the Holocaust in the United States. The scene towards the end of Night of the Living Dead where we watch on television as the sheriff and his men hunt down and destroy zombies, and kill the African-American survivor, can be read in the context of the stories of the Nazi Einsatzgruppen, the SS death squads whose role was to search out and murder Jews, gypsies and others who were unwanted in the 
conquered territories. However, the scene also has a general resonance with those reduced to bare life including displaced people, people denied the protection of the state.

We must not forget the literal meaning of the Muselmann, that is, the Muslim. ${ }^{6}$ I have discussed the background to the use of the term in the camps, the association of Muslims with total, mindless submission. This link also works the other way round. In the post-9/11 American fear of Islamic terrorists, Muslims can get figured as zombies. Referencing the historical association of Muslims with submission, and with the Muselmann, a contributor to an Internet discussion board using the name 'buttub' wonders about the increase in zombie films in the 2000s. S/he tells us that, 'the theory that most interests me, and that strikes me as likely most responsible for zombie mania, is that our culture's zombie fascination stems from widespread fear of Muslim terrorists' (buttub 2009). Hamako makes the same point:

[The] Orientalist characterization of Muslims is not different ... from the characterization of modern zombies. The modern zombie expresses Orientalist fears of violent 'Islamic' (and perhaps soon, 'Confucian') opposition to modernity and secularism. ${ }^{7}$

Where Dendle and Bishop focus on the apocalypse aspect of the zombie apocalypse motif, buttub and Hamako identify the continuity with the discursive construction of the Muslim. The emphasis on apocalypse does not account for why the apocalyptic vehicle should be zombies. The orientalist connection of zombies with Muslims does. The zombie apocalypse, then, becomes a meaningful way to represent the so-called Islamic terrorist threat to the United States.

Awful as the Muselmänner state is, it is by no means unique. Alexander Esquemelin was a Dutchman who was indentured with the French West Indies Company and shipped to Tortuga, an island off the coast of Haiti, in the seventeenth century. He wrote a book called Bucaniers of America:

Esquemelin deplores the condition of the many men kidnapped in Europe as 'servants' and sold as slaves. These bonded men, he asserts, are used worse than African slaves; for their masters, with only three years to get their money's worth, often extracted that value at the price of the worker's life. Pressed beyond the limits of human endurance, they literally take leave of their senses: 'These miserable kidnap'd people, are frequently subject to a certain disease, which in those parts, is called Coma; being a total privation of the senses. And this distemper is judged to proceed from their hard usage.' Experienced as a coma in the days when Haiti was called Hispaniola, this state of death-in-life induced by 


\section{The Trouble with Zombies}

the [quoting Joan Dayan] 'reduction of human into thing for the ends of capital' is now called zombification. The zombie, like the comatose indentured servant, is a being whose identity and will are slaughtered in service to the exactions of unfree labor. (Mackie 2009: 135)

We find here a more direct connection between the condition of the Muselmann removed from the protection of the state and, as bare life, reduced to the barest condition of the experience of life, and the classical idea of zombies.

Agamben reinforces the Muselmann's threshold state. He writes: "That one cannot truly speak of "living beings" is confirmed by all witnesses. Améry and Bettleheim define them as "walking corpses" (1999: 64). Agamben provides this reading:

It is ... possible to understand the decisive function of the camps in the system of Nazi biopolitics. They are not merely the places of death and extermination; they are also, and above all, the site of the production of the Muselmann, the final biopolitical substance to be isolated in the biological continuum. Beyond the Muselmann lies only the gas chamber. (1999: 85)

We can now understand what is so terrifying about the zombie. It is not that the zombie reminds us of our own forthcoming demise but that the zombie is the mythic expression of bare life in the modern world. The zombie apocalypse is the fantastic representation of the modern state being overwhelmed by the bare life which underpins its existence; the bare life that is lived by those people excluded from the privileges of citizenship and rights. This includes those displaced people who, for many reasons, seek entry to Western states. In the neoliberal world, where inclusion has been supplanted by exclusion, or in Agamben's terms where the state of exception is becoming the norm, those attempting to gain entry to the state are a part of a continuity with those within the state - all are treated as bare life to a greater or less extent, all have the possibility of being reduced to the condition of Muselmänner.

\section{Zombification and the Modern State}

Displaced people, that is those officially classified as illegal immigrants, asylum seekers, refugees and the like, are bare life striving to enter states where they will be given protection. Those states experience them as an unregulated threat to life within the border. As Aihwa Ong writes: 'In camps of the disenfranchised or displaced, bare life becomes the ground for political claims, if not for citizenship, then for the right 
to survive' (2006: 500). At the same time, in the modern state, bare life is the basis for the treatment even of citizens of the state. The zombie is the mythic expression of bare life striving to enter the state but, in addition, the zombie is the condition that awaits all of us from whom the state withdraws protection. The zombies besieging the places of sanctuary in zombie apocalypse films can be read as displaced people seeking recognition from the countries of the West.

I should add that, in the modern state, the discourse of race can function to mark the limits of who might be reduced to bare life. Michel Foucault argues that:

It is indeed the emergence of this biopower that inscribes it in the mechanisms of the State. It is at this moment that racism is inscribed as the basic mechanism of power, as it is exercised in modern States. As a result, the modern State can scarcely function without becoming involved with racism at some point, within certain limits and subject to certain conditions. (2003: 254)

I have already quoted Agamben linking the new centrality of bare life in the modern state to the historical elaboration of biopower as a political technology for the management of populations founded in what Foucault describes as 'the fundamental biological fact that human beings are a species' (2007: 1). Race can be used to exclude people from the benefits of state membership, and zombies can be read as racially Other. In the Canadian film, Fido (2006), some tamed zombies are used as domestics. Constructed as racially Other, indeed similar to the way that African-American slaves were identified, these zombies may be thought of as bare life given the most menial and unprotected forms of labour. We are told that the surviving zombies in the British film Shaun of the Dead (2004) meet a similar fate. Similarly, the displaced people attempting to enter Western states are also racialised as Other and, indeed, achieving entry either legally or illegally they very often occupy the most menial domestic roles.

But, the zombies are also an image of what we, members of the modern state, might become. In the modern state bare life founds the political order. In the neoliberal version of that state, where rights are dependent on what people within the border of the state can offer to the economic wellbeing of the state, the degree to which one is reprieved from bare life depends on one's economic worth. In this way, within the state, labour returns as an inverse measure of zombification. Bare life is the prospect for those the state considers of little or no economic worth and withdraws its protection. In zombie films it is the local population who are turned into zombies and become the threat 
to the remaining citizens. While, as I have argued, these zombies can be read as threatening, racially Othered, displaced people, they can also be read as the citizens of the state whom that state no longer finds economically useful. In many recent zombie films one of the more shocking elements is how ordinary the zombies look. They often have little in the way of physical transformation. Any member of the neoliberal state might find themselves turned into a zombie. This is also an aspect of the horror engendered in recent zombie films. In the American television series, The Walking Dead, which began in 2010, Rick Grimes, a deputy sheriff, wakes up from a coma to find that almost everybody in the United States has become a zombie. Neoliberal America has imploded in a zombie apocalypse.

Bare life, as I have explained, has a dual meaning. In the first place it refers to the lack of legal protection by the state. Without that protection the person reduced to bare life can become transformed into the second understanding of bare life: the liminal condition of death in life, coma. Indeed such a person can become one of the living dead. This is the existential condition represented in the zombie. The equation of the zombie and the displaced person occurs through the construction of bare life in both aspects of the term. The new fascination with zombie apocalypse texts can be understood in relation to, but is not limited to, the increasing anxiety of members of Western states founded in the threat that these states feel is posed by displaced people. Both manifestations of bare life are described using the same discursive terms. The fear of what is perceived to be an external threat from the racialised, zombie Other helps those who live in Western states to repress the awareness of how easily their own existence can become reduced to bare life.

\section{Acknowledgements}

I would like to thank Joke Hermes, Suvendrini Perera, Joseph Pugliese and Holly Randell-Moon for their comments on earlier versions of this article.

A companion piece to this essay, titled 'Zombie Trouble: Zombie Texts, Bare Life and Displaced People' is set to appear in the European Journal of Cultural Studies vol 14, no 3, 2011.

\footnotetext{
Notes

1. See UNHCR excel spread sheet, 'Total refugee population by country of asylum 1960-2009, \& Total refugee population by origin 1960-2009' (n.d.).

2. See UNHCR Report, 'The state of the world's refugees' (2000).
} 


\section{Somatechnics}

3. Joan Dayan uses the term zombi in preference to zombie. 'Zombi' is a French usage. Dayan links the term to Jean Zombi who, as she writes in Haiti, History and the Gods, 'In 1804, during Dessalines' massacre of the whites ... earned a reputation for brutality' (1998: 36). Dayan goes on to write that: 'Variously reconstituted, and adaptable to varying events, Zombi crystallizes the crossing not only of spirit and man in vodou practices but the intertwining of black and yellow, African and Creole in the struggle for independence' (1998: 36). Dayan argues that the Haitian usage of zombi to describe the undead originates in Jean Zombi's name.

4. While not relevant to my argument here, the power of this scene can be understood in terms of the female version of the Oedipus complex or, as Carl Jung called it, the Electra complex.

5. See Eric Hamako's posted response to Kim Paffenroth in Paffenroth (2009).

6. An excellent discussion of the relationship between Muselmann and Muslim, couched in the context of the incarceration of Muslims at Guantánamo Bay, can be found in Joseph Pugliese (2009).

7. See Eric Hamako's posted response to Kim Paffenroth in Paffenroth (2009).

\section{References}

28 Days Later, film, directed by Danny Boyle. USA: 20th Century Fox Home Entertainment, 2003.

Agamben, Giorgio (1998), Homo Sacer: Sovereign Power and Bare Life, trans. D. HellerRoazen, Stanford, CA: Stanford University Press.

Agamben, Giorgio (1999), Remnants of Auschwitz: The Witness and The Archive, trans. D. Heller-Roazen, New York: Zone Books.

Anidjar, Gil (2003), The Jew, the Arab: A History of the Enemy, Stanford, CA: Stanford University Press.

Bishop, Kyle (2009), 'Dead man still walking: Explaining the zombie renaissance', Journal of Popular Film E Television, 37:1, pp. 16-25.

buttub (2009), 'Notes on zombies', Ghost Island, 16 July, http://ghostisland. wordpress.com/2009/07/16/notes-on-zombies/

Cannon, JoAnn (1992), 'Canon-formation and reception in contemporary Italy: The case of Primo Levi', Italica, 69:1, pp. 30-44.

'Capcom's million-selling series, Resident Evil, expanding to the Nintendo GameCube and Sony PlayStation2!' (2004), CAPCOM, 4 November, http://www.capcom.co.jp/ ir/english/news/html/e041101.html

Casares, Cindy (2009), 'George Romero: The Cuban American who created zombies as we know them', GUANABEE, 1 November, http://guanabee.com/2009/11/ george-romero-the-cuban-american-who-created-zombies-as-we-know-them/

Children of Men, film, directed by Alfonso Cuarón. UK: Universal Home Entertainment, 2007.

Comaroff, Jean and John L. Comaroff (2002), 'Alien nation: Zombies, immigrants, and millennial capitalism', South Atlantic Quarterly, 101:4, pp. 779-805.

'Dawn of the Dead' (1979), Variety, January, http://www.variety.com/review/ VE1117790260.html?categoryid=31\&cs=1\&query=Dawn+of+the+Dead

Dawn of the Dead, film, directed by George A. Romero. Australia: Umbrella Entertainment, 2004.

Dayan, Joan (1997), 'Vodoun, or the voice of the gods', in M. Fernandez Olmos and L. Paravisini-Gebert (ed.), Sacred Possessions: Vodou, Santeria, Obeah, and the Caribbean, New Brunswick, NJ: Rutgers University Press, pp. 13-36. 


\section{The Trouble with Zombies}

Dayan, Joan (1998), Haiti, History and the Gods, Berkeley: University of California Press.

Dendle, Peter (2007), 'The zombie as barometer of cultural anxiety', in N. Scott (ed.), Monsters and the Monstrous: Myths and Metaphors of Enduring Evil, Amsterdam: Rodpi, pp. $45-57$.

Downey, Anthony (2009), 'Zones of indistinction: Giorgio Agamben's "bare life" and the politics of aesthetics', Third Text, 23:2, pp. 109-25.

Ebert, Roger (1967), 'The Night of the Living Dead', rogerebert.com, 5 January, http://rogerebert.suntimes.com/apps/pbcs.dll/article?AID=/19670105/REVIEWS/ $701050301 / 1023$

Fido, film, directed by Andrew Currie. Australia: Sony Pictures Home Entertainment, 2008.

Foucault, Michel (2003), 'Society Must Be Defended': Lectures at the College de France, 1975-1976, ed. M. Bertani, A. Fontana and F. Ewald, trans. D. Macey, London: Penguin.

Foucault, Michel (2007), Security, Territory, Population: Lectures at the College de France, 1977-1978, ed. M. Senellart, F. Ewald and A. Fontana, trans. G. Burchell, Basingstoke, NY: Palgrave Macmillan.

Grahame-Smith, Seth (2009), Pride and Prejudice and Zombies, Philadelphia: Quirk Books.

Hockensmith, Steve (2010), Pride and Prejudice and Zombies: Dawn of the Dreadfuls, Philadelphia: Quirk Books.

Levi, Primo (1996), Survival in Auschwitz: The Nazi Assault on Humanity, trans. S. Woolf, New York: Touchstone.

Mackie, Erin (2009), Rakes, Highwaymen, and Pirates: The Making of the Modern Gentleman in the Eighteenth Century, Baltimore: John Hopkins University Press.

Merritt, Stephanie (2009), 'Pride and Prejudice and Zombies by Jane Austen and Seth Grahame-Smith', The Guardian, 6 December, http://www.guardian.co.uk/books/ 2009/dec/06/pride-prejudice-zombies-grahame-smith

Night of the Living Dead, film, directed by George A. Romero. Australia: Rajon Vision, 2004

Ong, Aihwa (2006), 'Mutations in citizenship', Theory, Culture E Society, 23:2-3, pp. 499-505.

Paffenroth, Kim (2009), 'Dawn of the Dead (1978): Zombies and human nature', In Media Res: A Media Commons Project, 30 September, http://mediacommons. futureofthebook.org/imr/2009/08/27/dawn-dead-1978-zombies-and-human-nature

Pegg, Simon (2008), 'The dead and the quick', The Guardian, 4 November, http:// www.guardian.co.uk/media/2008/nov/04/television-simon-pegg-dead-set

Pugliese, Joseph (2009), 'Apostrophe of empire: Guantanamo Bay, Disneyland', borderlands, 8:3, pp. 1-26, http://www.borderlands.net.au/vol8no32009/pugliese apostrophe.pdf

'Resident Evil' (n.d.), Box Office Mojo, http://www.boxofficemojo.com/movies/?id= residentevil.htm

Resident Evil, film, directed by Paul W.S. Anderson. USA: Columbia TriStar Home Entertainment, 2003.

Rocchi, James (2008), 'Interview: 'Diary of the Dead' director George A. Romero', moviefone, 16 February, http://www.cinematical.com/2008/02/16/interview-diary-ofthe-dead-director-george-a-romero/

Scarry, Elaine (1985), The Body in Pain: The Making and Unmaking of the World, New York: Oxford University Press. 


\section{Somatechnics}

Shaun of the Dead, film, directed by Edgar Wright. UK: Universal Home Entertainment, 2004.

Stratton, Jon (2009), “Welcome to paradise': Asylum seekers, neoliberalism, nostalgia and Lucky Miles', Continuum: Journal of Media $\mathcal{E}$ Cultural Studies, 23:5, pp. 629-45.

The Flesh Eaters, film, directed by Jack Curtis. USA: Dark Sky Films, 2005.

'The state of the world's refugees 2000: Fifty years of humanitarian action - chapter 7 : Asylum in the industrialized world' (2000), UNHCR The State of the World's Refugees, 1 January, http://www.unhcr.org/cgi-bin/texis/vtx/search?page=search\&docid= 3ebf9bb10\&query=asylum seekers 1960 .

The Walking Dead, television series, created by Frank Darabont. non-USA: Fox International Channels, 2010.

'Total refugee population by country of asylum, 1960-2009, \& Total refugee population by origin, 1960-2009' (n.d.), UNHCR Statistical Online Population Database, United Nations High Commissioner for Refugees (UNHCR), http://www.unhcr.org/pages/ 4a0174156.html 